Article

\title{
Ammonia Recovery from Digestate Using Gas-Permeable Membranes: A Pilot-Scale Study
}

\author{
Berta Riaño ${ }^{1, *}$, Beatriz Molinuevo-Salces ${ }^{1}$, Matías B. Vanotti ${ }^{2}$ and María Cruz García-González ${ }^{1}$ \\ 1 Agricultural Technological Institute of Castilla y León. Ctra. Burgos, km. 119, 47071 Valladolid, Spain; \\ ita-molsalbe@itacyl.es (B.M.-S.); gargonmi@itacyl.es (M.C.G.-G.) \\ 2 Agricultural Research Service, Coastal Plains Soil, Water and Plant Research Center, United States \\ Department of Agriculture, 2611 W. Lucas St., Florence, SC 29501, USA; matias.vanotti@usda.gov \\ * Correspondence: riairabe@itacyl.es; Tel.: +34-983-317-384
}

check for updates

Citation: Riaño, B.; Molinuevo-Salces, B.; Vanotti, M.B.; García-González, M.C. Ammonia Recovery from Digestate Using Gas-Permeable Membranes: A Pilot-Scale Study. Environments 2021, 8, 133. https:// doi.org/10.3390/environments 8120133

Academic Editor: Manuel Soto

Received: 27 October 2021

Accepted: 22 November 2021

Published: 25 November 2021

Publisher's Note: MDPI stays neutral with regard to jurisdictional claims in published maps and institutional affiliations.

Copyright: (c) 2021 by the authors. Licensee MDPI, Basel, Switzerland. This article is an open access article distributed under the terms and conditions of the Creative Commons Attribution (CC BY) license (https:/ / creativecommons.org/licenses/by/ $4.0 /)$.

\begin{abstract}
The reduction and recovery of nitrogen $(\mathrm{N})$ from anaerobically digested manure (digestate) is desirable to mitigate $\mathrm{N}$-related emissions, mainly ammonia and nitrate, derived from digestate land application in nutrient-saturated zones. This work reports the results of a gas-permeable membrane (GPM) pilot-scale plant to recover ammonia from digestate in the framework of the EU project Ammonia Trapping. The total ammonia nitrogen (TAN) concentration in digestate was reduced by $34.2 \%$ on average (range $9.4-57.4 \%$ ). The recovery of TAN in the trapping solution in the form of a $\left(\mathrm{NH}_{4}\right)_{2} \mathrm{SO}_{4}$ solution averaged $55.3 \%$ of the removed TAN, with a TAN recovery rate of $16.2 \mathrm{~g} \mathrm{~N} \mathrm{~m}^{-2} \mathrm{~d}^{-1}$ (range between 14.5 and $21.0 \mathrm{~g} \mathrm{~N} \mathrm{~m}^{-2} \mathrm{~d}^{-1}$ ). The TAN concentration in the trapping solution achieved a value of up to $35,000 \mathrm{mg} \mathrm{N} \mathrm{L}^{-1}$. The frequent change of the trapping solution has been proven as an efficient strategy to improve the overall performance of the GPM technology.
\end{abstract}

Keywords: anaerobic digestion; digestate; gas-permeable membranes; ammonia recovery

\section{Introduction}

The implementation of anaerobic digestion treatment has increased in recent decades in order to minimize the environmental impacts of animal manures whilst producing renewable energy in the form of biogas [1,2] and, more recently, upgrading it to biomethane [3]. In addition, anaerobic digestion transforms the manure into a digestate, which is a biologically stable and partially sanitized product with high nutrient content that can be used as fertilizer. However, the land application of anaerobic digestate is also found to be a source of significant N-related emissions [2,4]. During anaerobic digestion, the organic nitrogen content in the waste is transformed into a mineral form, i.e., ammonia $\left(\mathrm{NH}_{3}\right)$. These emissions can cause air and water pollution, which can negatively affect the biodiversity, vegetation and human health. Current European regulations on air quality are becoming more restrictive and have established percentage reduction commitments for $\mathrm{NH}_{3}$ annual emissions for each European country to be achieved by 2020 and 2030 [5]. In addition to application restrictions due to air quality regulations, there are also water quality regulations, such as the Nitrate Directive, which limits the use of digestate as fertilizer in order to reduce nitrate leaching, particularly in nitrate-vulnerable zones [6]. Moreover, the transportation of the digestate across agricultural fields can become quite expensive due to its high water content, which could affect the overall sustainability of the biogas plant. Therefore, technical solutions are needed for decreasing the nitrogen $(\mathrm{N})$ content from anaerobic digestate in order to reduce the environmental risks associated with its use as fertilizer in nutrient-saturated zones.

The most common technology for nitrogen recovery from livestock wastewater is air stripping [7]. Other technologies that have been researched for the recovery of nitrogen are: zeolite adsorption through ion exchange [8], struvite precipitation [9], reverse osmosis [10] and gas-permeable membrane (GPM) technology [11]. Recently, Munasinghe-Arachchige 
and Nirmalakhandan [12] performed a multicriteria analysis to rank these techniques considering ten performance criteria, giving priority to economic and energetic aspects, and they concluded that the GPM technology is the preferred option. In this technology, GPMs are submerged in the wastewater and $\mathrm{NH}_{3}$ passes through the membrane pores by diffusion from high to low concentration (Figure 1). An acidic solution, used as a trapping solution, circulates on the other side of the membrane, recovering the $\mathrm{NH}_{3}$ as a valuable $\left(\mathrm{NH}_{4}\right)_{2} \mathrm{SO}_{4}$ solution [13]. The efficiency of the GPM technology depends on the availability of $\mathrm{NH}_{3}$ gas in the wastewater, where $\mathrm{NH}_{3}$ gas and $\mathrm{NH}_{4}{ }^{+}$(the ionic form) are in equilibrium. The main factor influencing this equilibrium is the $\mathrm{pH}$ [14]. Thus, the alkaline $\mathrm{pH}$ causes the dissociation of the ion $\mathrm{NH}_{4}{ }^{+}$and forms free $\mathrm{NH}_{3}$ that can cross the membrane, being captured by the acidic solution. Low-rate aeration has been demonstrated as a cost-effective method to increase the $\mathrm{pH}$ of the livestock wastewater, compared with the addition of alkali chemicals [14].

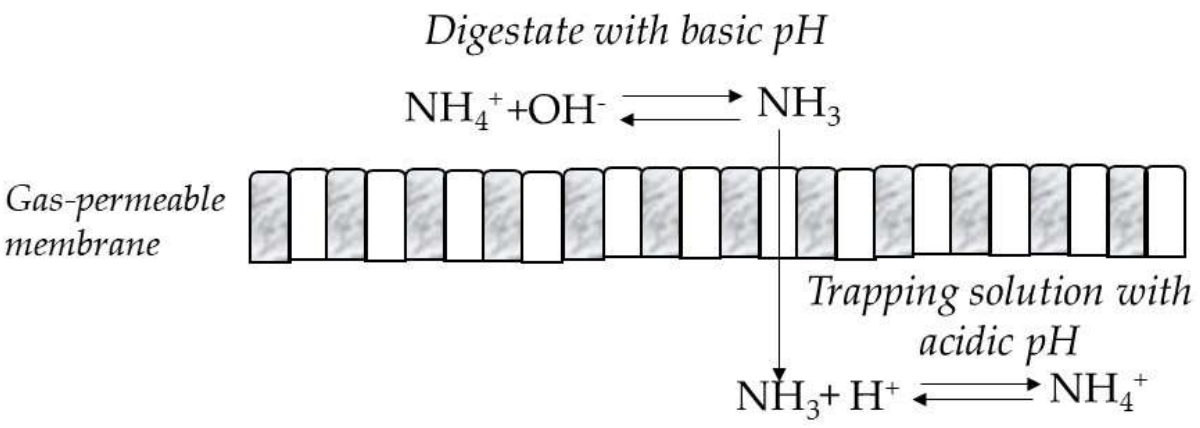

Figure 1. Cross-sectional diagram of a gas-permeable membrane.

This novel technology has been successfully applied to recover nitrogen from livestock wastes and anaerobic digestates at laboratory scale [13-18]. Another approach of this technology would be to treat ammonium-rich manure prior to anaerobic digestion feeding. The removal of $\mathrm{NH}_{3}$ from manure prior to anaerobic digestion would minimize the inhibition caused by this compound on methanogenic microorganisms, improving both biogas quality and quantity $[19,20]$.

The EU project Ammonia Trapping was established to reduce $\mathrm{NH}_{3}$ emissions and recover $\mathrm{N}$ from livestock waste and anaerobic digestates using GPM technology through the transfer of knowledge from the lab-scale level to field pilot-scale level. Previously, in this project, the GPM technology was successfully demonstrated in a pilot-scale plant that captured $\mathrm{NH}_{3}$ from raw swine manure in a sow farm located in the north of Spain [21]. The present study was another objective of the Ammonia Trapping project, to determine the performance and efficiency of the GPM technology at pilot scale, recovering $\mathrm{NH}_{3}$ from anaerobically digested swine manure (digestate).

\section{Materials and Methods}

\subsection{Location and Origin of Digestate}

The pilot-scale plant was tested in batch operation during 11 months (from January to December 2019) for ammonia recovery from digestate in an agricultural anaerobic codigestion plant located in Juzbado (Salamanca, Spain). The anaerobic co-digestion plant treated mainly swine manure from a finishing farm located in Salamanca (Spain), together with other co-substrates such as tobacco powder and cereal powder (pre-cleaned maize residue, broken kernels) at approximately $35^{\circ} \mathrm{C}$ (mesophilic range) and with a hydraulic retention time (HRT) between 70 and 80 days. It generated approximately $6000 \mathrm{~m}^{3}$ of digestate per year. The mean concentrations for digestate for each batch experiment are presented in Table 1. 
Table 1. Characteristics for the digestate in the different batch experiments.

\begin{tabular}{|c|c|c|c|c|c|c|c|c|}
\hline Parameter & A1 & B1 & B2 & B3 & B4 & B5 & $\mathrm{C} 1$ & $\mathrm{C} 2$ \\
\hline $\mathrm{pH}$ & 8.32 & 7.75 & 8.26 & 8.60 & 8.41 & 8.45 & 7.40 & 7.92 \\
\hline Alkalinity $\left(\mathrm{mg} \mathrm{L}^{-1}\right)$ & 23,772 & 20,207 & 19,528 & 22,363 & 21,047 & 26,103 & 14,722 & 21,221 \\
\hline TKN (mg N L $\left.{ }^{-1}\right)$ & $3451 \pm 3$ & $3255 \pm 135$ & $2990 \pm 14$ & $3384 \pm 14$ & $3311 \pm 72$ & n.d. & $2629 \pm 33$ & $3854 \pm 40$ \\
\hline Initial alkalinity: initial TAN ratio & 8.54 & 8.05 & 7.58 & 7.65 & 8.38 & 9.28 & 5.58 & 7.13 \\
\hline $\mathrm{TS}\left(\mathrm{g} \mathrm{L}^{-1}\right)$ & $75.9 \pm 8.9$ & $57.4 \pm 2.0$ & $66.0 \pm 14.2$ & $59.8 \pm 5.4$ & $68.1 \pm 0.7$ & n.d. & $32.2 \pm 1.1$ & $55.2 \pm 6.0$ \\
\hline $\operatorname{VS}\left(\mathrm{g} \mathrm{L}^{-1}\right)$ & $33.7 \pm 4.9$ & $27.7 \pm 0.7$ & $31.3 \pm 6.7$ & $28.7 \pm 3.1$ & $30.7 \pm 0.1$ & n.d. & $16.5 \pm 1.0$ & $28.6 \pm 2.0$ \\
\hline $\operatorname{CODt}\left(\mathrm{mg} \mathrm{L}^{-1}\right)$ & $34,958 \pm 3514$ & $29,752 \pm 492$ & $31,358 \pm 4089$ & $39,202 \pm 2879$ & $27,602 \pm 7570$ & n.d. & $23,461 \pm 2365$ & $41,034 \pm 2631$ \\
\hline TVFA (mg COD L $\left.{ }^{-1}\right)$ & $240.9 \pm 18.5$ & $85.1 \pm 0.6$ & $406.5 \pm 41.3$ & $456.7 \pm 6.2$ & $160.5 \pm 42.0$ & n.d. & $230.6 \pm 51.2$ & $285.9 \pm 73.1$ \\
\hline
\end{tabular}

n.d., not determined. 


\subsection{Pilot-Scale Plant Configuration}

The pilot-scale plant was placed next to the digestate storage tank of the anaerobic co-digestion plant and inside a shipping container. A schematic diagram of the pilot plant is shown in Figure 2. The pilot-scale plant consisted of: 1 . a digestate feeding pump; 2. a $5.85 \mathrm{~m}^{3}$ ammonia separation reactor tank with a module containing $16 \mathrm{e}-$ PTFE membrane panels (Figure 3A,B); 3. a blowing air pump for aeration and several air diffusers placed in the bottom of the reactor tank; 4 . a recirculation pump for mixing the reactor; 5 . a $0.25 \mathrm{~m}^{3}$ tank for ammonia concentration and for the acidic trapping solution (i.e., a solution of $\mathrm{H}_{2} \mathrm{SO}_{4} 1 \mathrm{~N}$ ) storage (Figure $3 \mathrm{C}$ ); 6. a recirculation pump for the acidic trapping solution, which is lifted to a distribution sealed pipeline connected to one end of the tubular membranes in the panels and collected in an open pipeline when exiting the tubular membranes in panels, being returned again to the concentrator tank by gravity (Figure 3D); 7. a heating blanket to heat the acidic trapping solution and reduce osmotic distillation; and 8. a programmable logic controller (PLC) control system to control aeration, heating and recirculation pumps and to monitor the $\mathrm{pH}$ and temperatures of the digestate and the trapping solution. The total surface of the membrane varied between 8.85 and $12.13 \mathrm{~m}^{2}$ in the batch experiments. This variation was due to the temporary closure of the membrane panels for maintenance reasons. The configuration of the pilot plant is described in more detail in the publication of Molinuevo-Salces et al. [21].

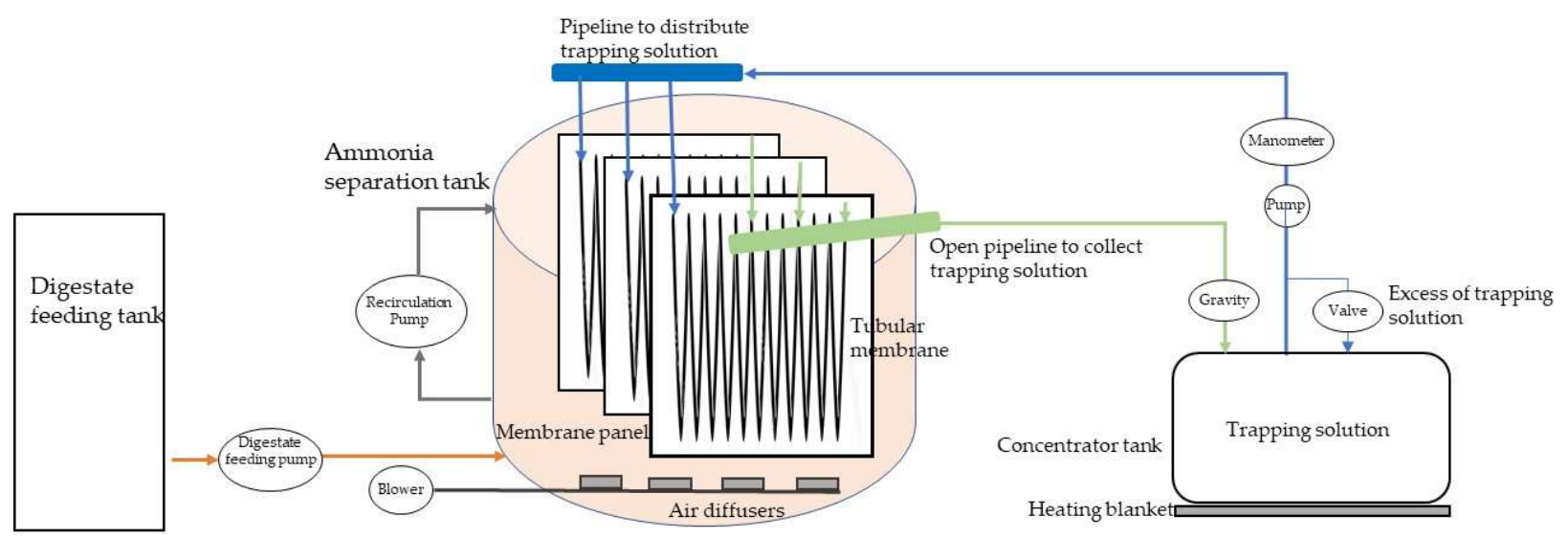

Figure 2. Schematic diagram of the pilot plant.

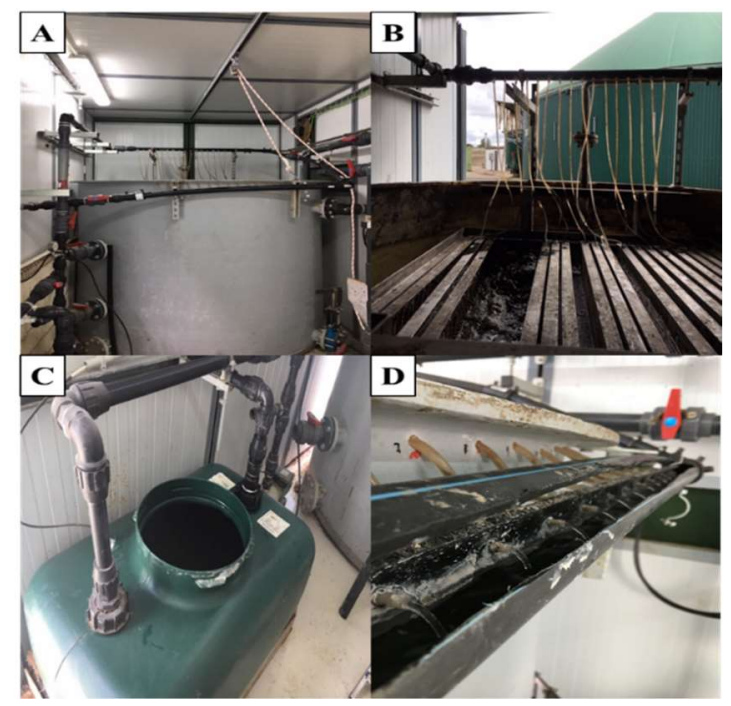

Figure 3. Pictures of the pilot plant located in the agro-industrial biogas plant. Ammonia separation reactor tank with a module of 16 parallel membrane panels $(\mathbf{A}, \mathbf{B})$, trapping solution tank $(\mathbf{C})$ and open pipeline to collect the trapping solution at the exit opening of the membranes (D). 


\subsection{Operational Procedure and Experimental Runs}

\subsubsection{Operational Procedure}

Two experiments that included several batch runs were carried out in order to evaluate the performance of the pilot-scale plant recovering ammonia from digestate. A standard operating procedure (SOP) was applied to all runs as follows. Digestate was pumped from a digestate storage tank to the ammonia separation reactor tank of the pilot-scale plant, reaching a total volume of approximately $5 \mathrm{~m}^{3}$. The digestate was mixed by using a recirculation pump working in on/off cycles of 20/10 seconds. The blowing air pump for the aeration of the digestate worked in discontinuous mode in on/off cycles of $180 / 180$ seconds to reach a $\mathrm{pH}$ of 8.5. To recover and concentrate ammonia, a volume of approx. $0.15 \mathrm{~m}^{3}$ of $1 \mathrm{~N} \mathrm{H}_{2} \mathrm{SO}_{4}$ was used as a trapping solution. To maintain the $\mathrm{pH}$ of the trapping solution below 2, concentrated $\mathrm{H}_{2} \mathrm{SO}_{4}$ (96-98\%, Panreac, Glenview, IL, USA) was manually added to the trapping solution to an endpoint of $\mathrm{pH}<1$ whenever the $\mathrm{pH}$ of the solution increased up to 2 .

\subsubsection{Effect of the Change of the Trapping Solution on TAN Removal from Digestate (Experiment I)}

Experiment I was performed to evaluate the percentage of TAN that could be removed from digestate by the pilot-scale plant by changing the trapping solution frequently. For this purpose, three consecutive acid-batch runs (namely A1, A2 and A3) were carried out over $27 \mathrm{~d}$ following the SOP described in Section 2.3.1. In each of them, a new trapping solution was used, while the same digestate was used during the whole experiment (for example, A2 started with new acid solution and the digestate left after A1 treatment). The operational parameters of each batch are presented in Table 2.

\subsubsection{Study of the Maximum TAN Concentration in the Trapping Solution (Experiment II)}

In order to assess the maximum TAN concentration that could be attained on the trapping solution, a fed-batch experiment was carried out (namely, experiment II). This fed-batch experiment consisted of using the same trapping solution (i.e., $1 \mathrm{~N}_{2} \mathrm{SO}_{4}$ ) during the whole experimental time but feeding the reactor with fresh digestate in each batch run (for example, B2 started with new digestate and the acidic solution left after B1 treatment). Experiment II lasted for 50 days. Five (B1-B5) consecutive batch runs were carried out in Experiment II. Table 2 shows the operational parameters during each batch of Experiment II. The SOP was as described in Section 2.3.1.

2.3.4. Comparison of the GPM Pilot Plant Performance during Treatment of Digestate and Raw Swine Manure

Four batch experiments were carried out for the evaluation of the performance of the pilot plant for recovering ammonia from the digestate (A1 from Experiment I, B1 from Experiment II, C1 and C2). Table 2 summarizes the operational parameters during each batch. The results of this evaluation were compared with those reported by MolinuevoSalces et al. [21], who evaluated the performance of the pilot-scale plant for recovering ammonia from swine manure.

\subsection{Sampling and Process Monitoring}

Initial samples of digestate were taken for each batch experiment and analyzed for $\mathrm{pH}$, total alkalinity, total solids (TS), volatile solids (VS), total chemical oxygen demand (TCOD), soluble chemical oxygen demand (SCOD), total volatile fatty acids (TVFA), TAN and total Kjeldahl nitrogen (TKN) (Table 1). Every day, liquid samples $(100 \mathrm{~mL})$ from the ammonia separation reactor tank and samples of the trapping solution $(10 \mathrm{~mL})$ from the ammonia concentrator tank were taken to monitor the $\mathrm{pH}$ and TAN concentration. These samples were refrigerated at $4{ }^{\circ} \mathrm{C}$ and transported to the laboratory for analyses once a week. The temperature in the digestate and in the acidic trapping solution were hourly recorded by the PLC and averaged daily. 
Table 2. Operational parameters during Experiment I (A1-A3), Experiment II (B1-B5) and two batches (C1-C2).

\begin{tabular}{|c|c|c|c|c|c|c|c|c|c|c|c|}
\hline & & \multicolumn{3}{|c|}{ Experiment I } & \multicolumn{5}{|c|}{ Experiment II } & \multirow[b]{2}{*}{$\mathrm{C} 1$} & \multirow[b]{2}{*}{$\mathrm{C} 2$} \\
\hline & & A1 & A2 & A3 & B1 & B2 & B3 & B4 & B5 & & \\
\hline Operation time & days & $1-7$ & $7-16$ & $16-27$ & $1-15$ & $15-29$ & $29-38$ & $38-44$ & $44-50$ & 18 & 7 \\
\hline Trapping solution & $\mathrm{m}^{3}$ & 0.15 & $0.15-0.14$ & 0.15 & $0.13-0.14$ & $0.13-0.14$ & $0.14-0.13$ & $0.13-0.11$ & $0.13-0.13$ & $0.13-0.15$ & 0.15 \\
\hline Digestate & $\mathrm{m}^{3}$ & $5.08-4.99$ & $4.99-4.79$ & $4.97-4.88$ & $5.05-5.05$ & $5.05-4.90$ & $5.06-4.86$ & $5.23-5.12$ & $5.08-4.99$ & $5.12-4.88$ & $5.16-5.14$ \\
\hline Membrane surface & $\mathrm{m}^{2}$ & 8.85 & 8.85 & 8.85 & 12.13 & 11.13 & 11.95 & 11.95 & 11.95 & 8.85 & 8.85 \\
\hline Temperature digestate & ${ }^{\circ} \mathrm{C}$ & $22.7 \pm 1.7$ & $20.7 \pm 0.7$ & $21.0 \pm 0.7$ & $27.2 \pm 1.14$ & $28.4 \pm 0.9$ & $29.4 \pm 1.8$ & $27.4 \pm 1.7$ & $28.6 \pm 1.1$ & $23.9 \pm 1.1$ & $18.4 \pm 0.7$ \\
\hline Temperature trapping solution & ${ }^{\circ} \mathrm{C}$ & $25.4 \pm 1.9$ & $23.8 \pm 1.1$ & $24.8 \pm 1.0$ & $28.8 \pm 1.3$ & $30.5 \pm 0.9$ & $31.9 \pm 1.7$ & $30.8 \pm 0.8$ & $32.6 \pm 2.9$ & $28.8 \pm 1.4$ & $22.7 \pm 0.8$ \\
\hline
\end{tabular}




\subsection{Analytical Methods and Calculations}

Analyses of TS, VS, TCOD, SCOD, TAN and TKN were performed in duplicate in accordance with APHA [22]. TS content was determined by drying the sample to a constant weight at $103-105^{\circ} \mathrm{C}$. The TS residue was ignited at $550{ }^{\circ} \mathrm{C}$ to constant weight and the weight lost on ignition was the VS content. TCOD and SCOD were determined following the closed reflux colorimetric method. TKN was measured according to the Kjeldahl digestion, distillation and titration method. TAN was measured according to the distillation and titration method. Total alkalinity and $\mathrm{pH}$ were monitored using a $\mathrm{pH}$ meter, the Crison Basic 20 (Crison Instruments S.A., Barcelona, Spain). Total alkalinity was determined by measuring the amount of standard sulfuric acid needed to bring the sample to a $\mathrm{pH}$ of 4.5 . The concentrations of acetate, propionate, butyrate, iso-butyrate, valerate, iso-valerate and caproate were determined using a gas chromatograph (Agilent 7890A, Santa Clara, CA, USA) equipped with a Teknokroma TRB-FFAP column of $30 \mathrm{~m}$ length and $0.25 \mathrm{~mm}$ i.d. followed by a flame ionization detector (FID). The carrier gas was helium $\left(1 \mathrm{~mL} \mathrm{~min}{ }^{-1}\right)$. The temperature of the detector and the injector was $280^{\circ} \mathrm{C}$. The temperature of the oven was set at $100{ }^{\circ} \mathrm{C}$ for $4 \mathrm{~min}$ and then increased to $155{ }^{\circ} \mathrm{C}$ for $2 \mathrm{~min}$ and thereafter increased to $210^{\circ} \mathrm{C}$. TVFA were calculated as the sum of those acids.

Free ammonia (FA) was calculated as un-ionized ammonia, using the equation of Hansen et al. [23] (Equation (1)):

$$
\mathrm{NH}_{3} / \mathrm{tNH}_{3}=\left(1+\left(10^{-\mathrm{pH}} / 10^{-(0.09018+2729.92 / \mathrm{T})}\right)^{-1}\right.
$$

where $\mathrm{NH}_{3}$ is the FA content, $\mathrm{tNH}_{3}$ is the total $\mathrm{NH}_{3}$ concentration, $\mathrm{T}$ (in Kelvin) and $\mathrm{pH}$ were measured in the digestate in the ammonia separation tank.

TAN removal in the digestate was calculated following Equation (2):

$$
\text { TAN removal }=\left(\mathrm{TAN}_{\mathrm{o}}-\mathrm{TAN}_{\text {final }}\right) / \mathrm{TAN}_{\mathrm{o}} \times 100
$$

where $\mathrm{TAN}_{\mathrm{o}}$ and TAN $\mathrm{N}_{\text {final }}$ are the initial and final TAN concentrations for each batch run, respectively, of the digestate being processed in the ammonia separation reactor tank.

\section{Results}

\subsection{Effect of the Change of the Trapping Solution on TAN Removal and Recovery (Experiment I)}

This experiment evaluated the effect of changing the trapping solution on TAN removal and recovery. For this purpose, three consecutive batch runs (namely A1, A2 and A3) were carried out over $27 \mathrm{~d}$. In each batch, a new trapping solution was used, whereas the same digestate was used during the whole experiment. The aeration provided successfully increased the digestate $\mathrm{pH}$ from an initial value of 8.3 to values above 9.1 (Table 3).

\begin{tabular}{|c|c|c|c|c|c|}
\hline Parameter & Unit & & A1 & A2 & A3 \\
\hline \multirow{2}{*}{$\mathrm{pH}$} & & Initial & 8.32 & 9.11 & 9.09 \\
\hline & & Final & 9.11 & 9.09 & 8.65 \\
\hline \multirow{2}{*}{ Alkalinity } & \multirow{2}{*}{$\mathrm{mg} \mathrm{CaCO} \mathrm{L}^{-1}$} & Initial & 23,772 & 15,702 & 11,625 \\
\hline & & Final & 15,702 & 11,625 & 9596 \\
\hline Removed TAN & $\%$ & - & 32.16 & 35.33 & 30.47 \\
\hline \multirow{2}{*}{ TAN in trapping solution } & \multirow{2}{*}{$\operatorname{mg~N~L}{ }^{-1}$} & Initial & 1357 & 1125 & 857 \\
\hline & & Final & 12,494 & 9719 & 7221 \\
\hline Recovered TAN in trapping solution & $\%$ & - & 57.52 & 30.67 & 20.67 \\
\hline TAN recovery rate & $\mathrm{g} \mathrm{N} \mathrm{m}^{-2} \mathrm{~d}^{-1}$ & - & 14.48 & 9.96 & 8.23 \\
\hline
\end{tabular}

Table 3. Changes in chemical characteristics of digestate during Experiment I.

The TAN concentration in the digestate decreased from $2783 \mathrm{mg} \mathrm{N} \mathrm{L}^{-1}$ to $849 \mathrm{mg} \mathrm{N} \mathrm{L}^{-1}$ in 27 days, leading to an overall TAN removal of $69 \%$ (Figure $4 \mathrm{~A}$ ). The recovery of TAN in 
the trapping solution gradually decreased from $57.5 \%$ in A1 to $30.7 \%$ in A2 and, finally, to $20.7 \%$ in A3 (Table 3). Consequently, the TAN recovery rate decreased with time, from $14.5 \mathrm{~g} \mathrm{~m}^{-2} \mathrm{~d}^{-1}$ in the first batch to $8.2 \mathrm{~g} \mathrm{~m}^{-2} \mathrm{~d}^{-1}$ in the third one. The reduction in the TAN recovery rate can be attributed to the marked decrease in FA content during the experiment, especially from day 17 , when it amounted to $95 \mathrm{mg} \mathrm{N} \mathrm{L}^{-1}$ (Figure 4A), which fits well with the FA threshold values reported in the literature. In this context, FA content in wastewater has been stated as one of the main factors affecting the TAN recovery by the GPM technology. For example, García-González and Vanotti [14] observed that the TAN recovery rate decreased when FA in manure was below $20 \mathrm{mg} \mathrm{L}^{-1}$. In addition, García-González et al. [19], in a 32-day experiment evaluating N recovery from digestate with the GPM technology, found that TAN recovery was linear until day 25 of the experiment, when the average FA in digestate was $69 \mathrm{mg} \mathrm{N} \mathrm{L}^{-1}$, and then the recovery rate drastically decreased.

In this experiment, a maximum TAN concentration in the acidic trapping solution of 13,134 $\mathrm{mg} \mathrm{N} \mathrm{L}^{-1}$ was achieved in A1 (Figure 4B), which means a concentration almost 5 times higher than in digestate.

\subsection{Study of the Maximum TAN Concentration in the Trapping Solution (Experiment II)}

In this experiment, a fed-batch assay was performed, where the same acidic trapping solution was used during the whole experimental period, whereas the digestate was changed for each batch (the acidic solution was recharged as needed with concentrated acid as the solution was being neutralized by the ammonia trapping, but the acidic solution was not replaced between batches).

Table 4 shows the chemical changes during Experiment II. The provided aeration successfully increased the $\mathrm{pH}$ in the digestate during each batch (approximately 0.34 to $0.79 \mathrm{pH}$ units). A decrease in the concentration of TAN in the digestate with time was observed for each batch (Figure 5A). However, there was also a reduction in TAN removal efficiency within each run, as the run progressed, shown by the TAN curves in Figure 5A. For example, for B1, most of the TAN was removed in the first 7 days of experimentation, whereas the removal from days 7 to 15 was negligible, even when the remaining TAN concentration in the digestate was around $1500 \mathrm{mg} \mathrm{N} \mathrm{L}^{-1}$. For B2, TAN removal took place mainly in the three first days of experimentation, when the TAN concentration in digestate decreased from $2575 \mathrm{mg} \mathrm{N} \mathrm{L}^{-1}$ to $1780 \mathrm{mg} \mathrm{N} \mathrm{L}^{-1}$. For the last batches (B3-B5), TAN removal mainly occurred on the first day. As a result, the TAN recovery rates during the different batch runs also decreased with time, from $14.9 \mathrm{~g} \mathrm{TAN} \mathrm{m}^{-2}$ day $^{-1}$ in B1 to $3.1 \mathrm{~g} \mathrm{TAN} \mathrm{m}^{-2}$ day $^{-1}$ in B5 (Table 4). Between 20.7 and $56.7 \%$ of the removed TAN was recovered as a $\left(\mathrm{NH}_{4}\right)_{2} \mathrm{SO} 4$ solution (Table 4).

Table 4. Chemical changes in digestate during Experiment II (fed-batch operation).

\begin{tabular}{|c|c|c|c|c|c|c|c|}
\hline Parameter & Unit & & B1 & B2 & B3 & B4 & B5 \\
\hline \multirow{2}{*}{$\mathrm{pH}$} & \multirow[b]{2}{*}{ - } & Initial & 7.75 & 8.26 & 8.14 & 8.41 & 8.45 \\
\hline & & Final & 8.54 & 8.60 & 8.76 & 8.94 & 9.18 \\
\hline Removed TAN & $\%$ & - & 37.78 & 41.59 & 19.47 & 6.49 & 4.34 \\
\hline \multirow{2}{*}{ TAN in the trapping solution } & \multirow{2}{*}{$\mathrm{mg} \mathrm{N} \mathrm{L}^{-1}$} & Initial & 373 & 12,860 & 24,160 & 30,236 & 27,139 \\
\hline & & Final & 16,698 & 24,682 & 30,492 & 32,321 & 20,589 \\
\hline $\begin{array}{l}\text { Recovered TAN in trapping } \\
\text { solution }\end{array}$ & $\%$ & - & 56.66 & 30.40 & 20.74 & 23.60 & 26.01 \\
\hline TAN recovery rate & $\mathrm{g} \mathrm{m}^{-2} \mathrm{~d}^{-1}$ & - & 14.89 & 10.97 & 8.73 & 3.64 & 3.14 \\
\hline
\end{tabular}




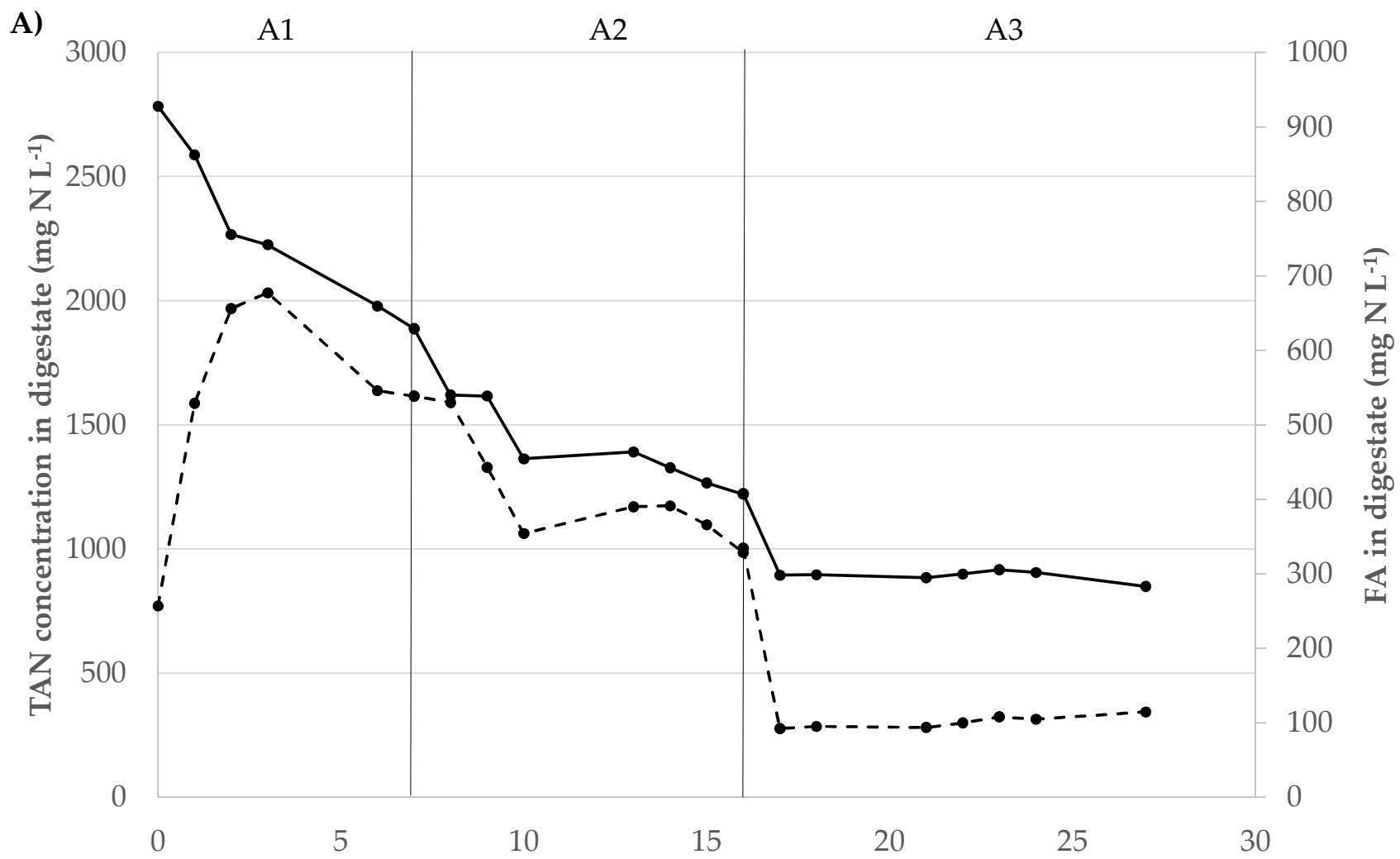

B)

A1

A2

A3

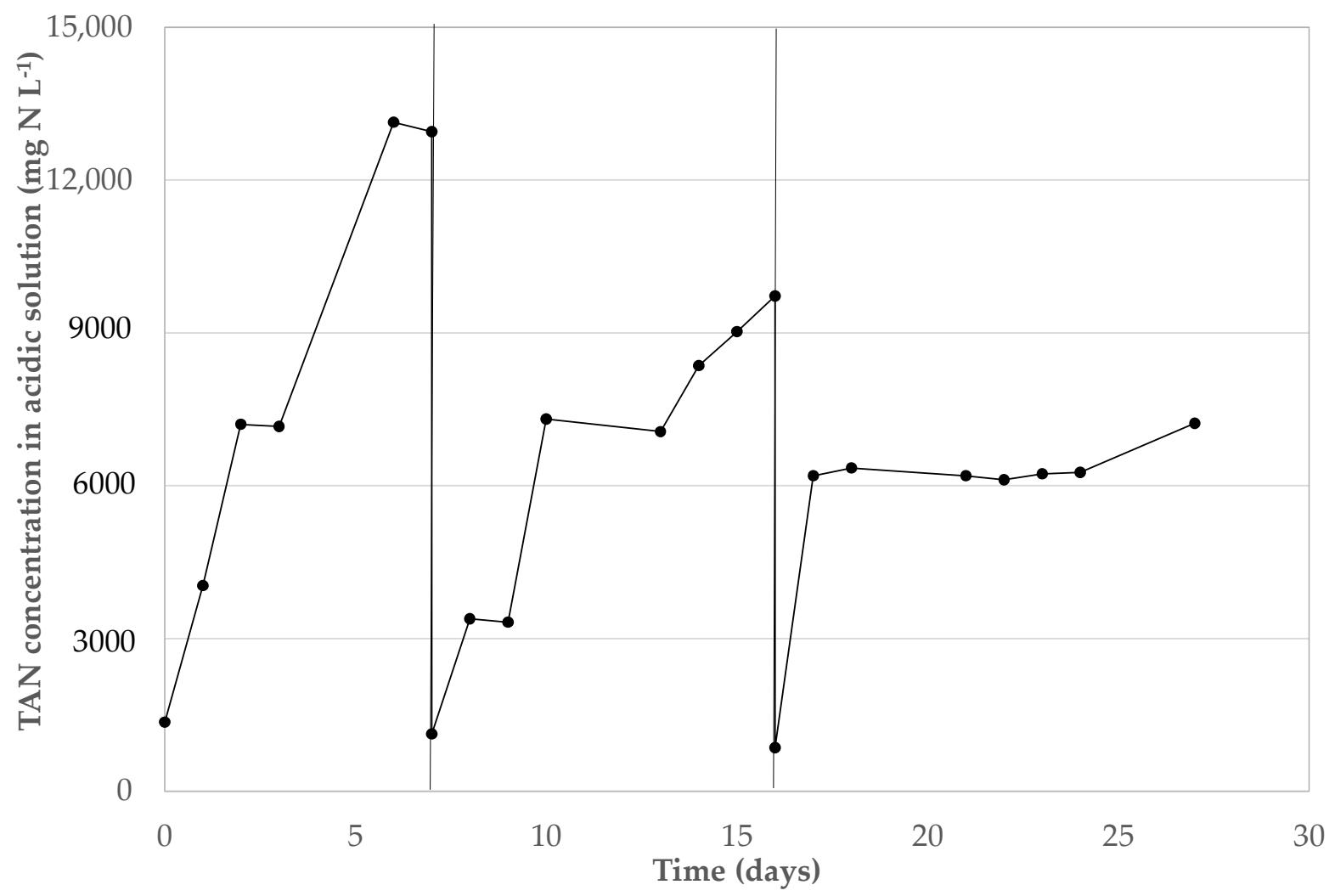

Figure 4. TAN (continuous line) and FA (dashed line) concentration in the digestate (A) and TAN concentration in the acidic trapping solution (B) in Experiment I. 


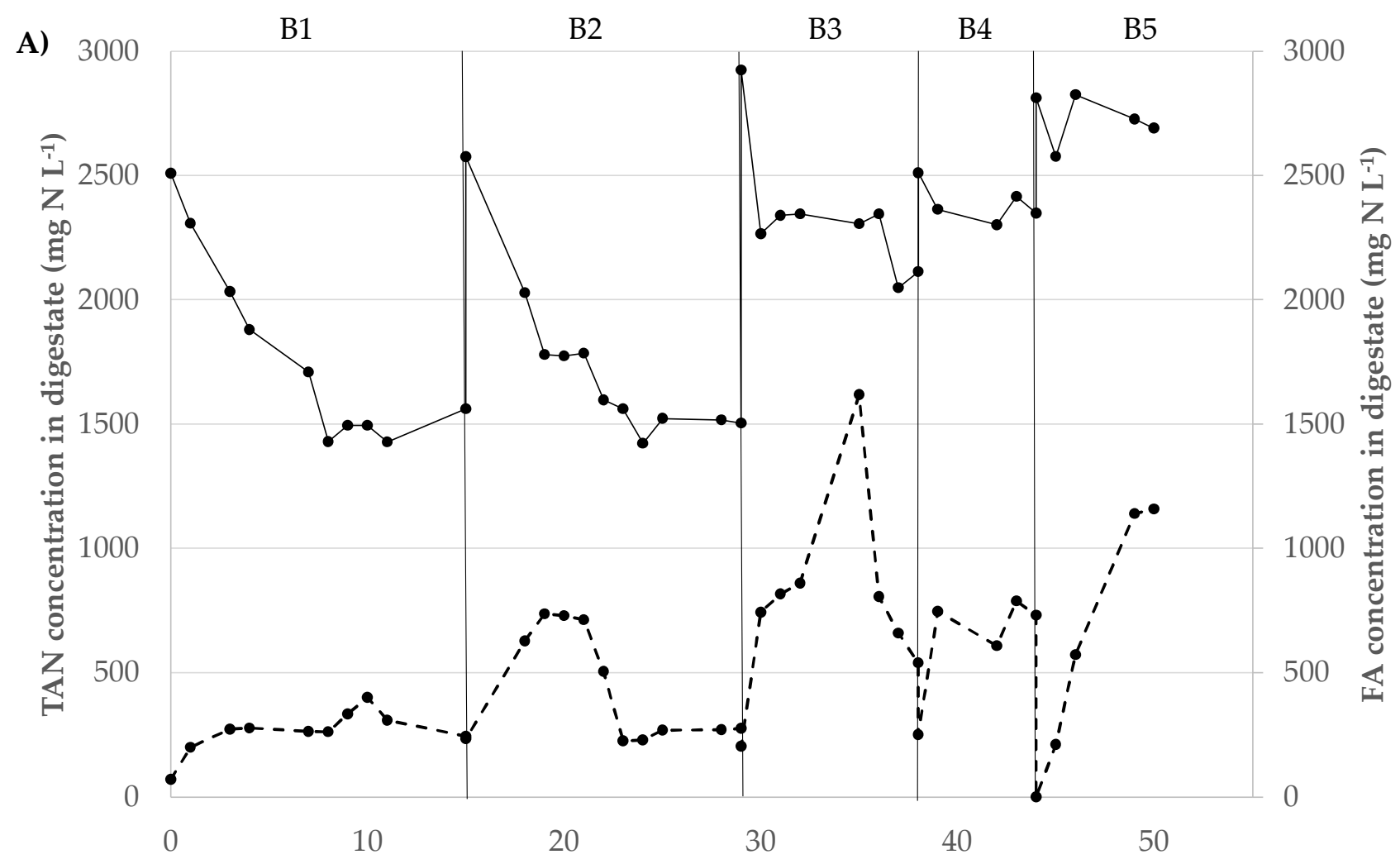

B)

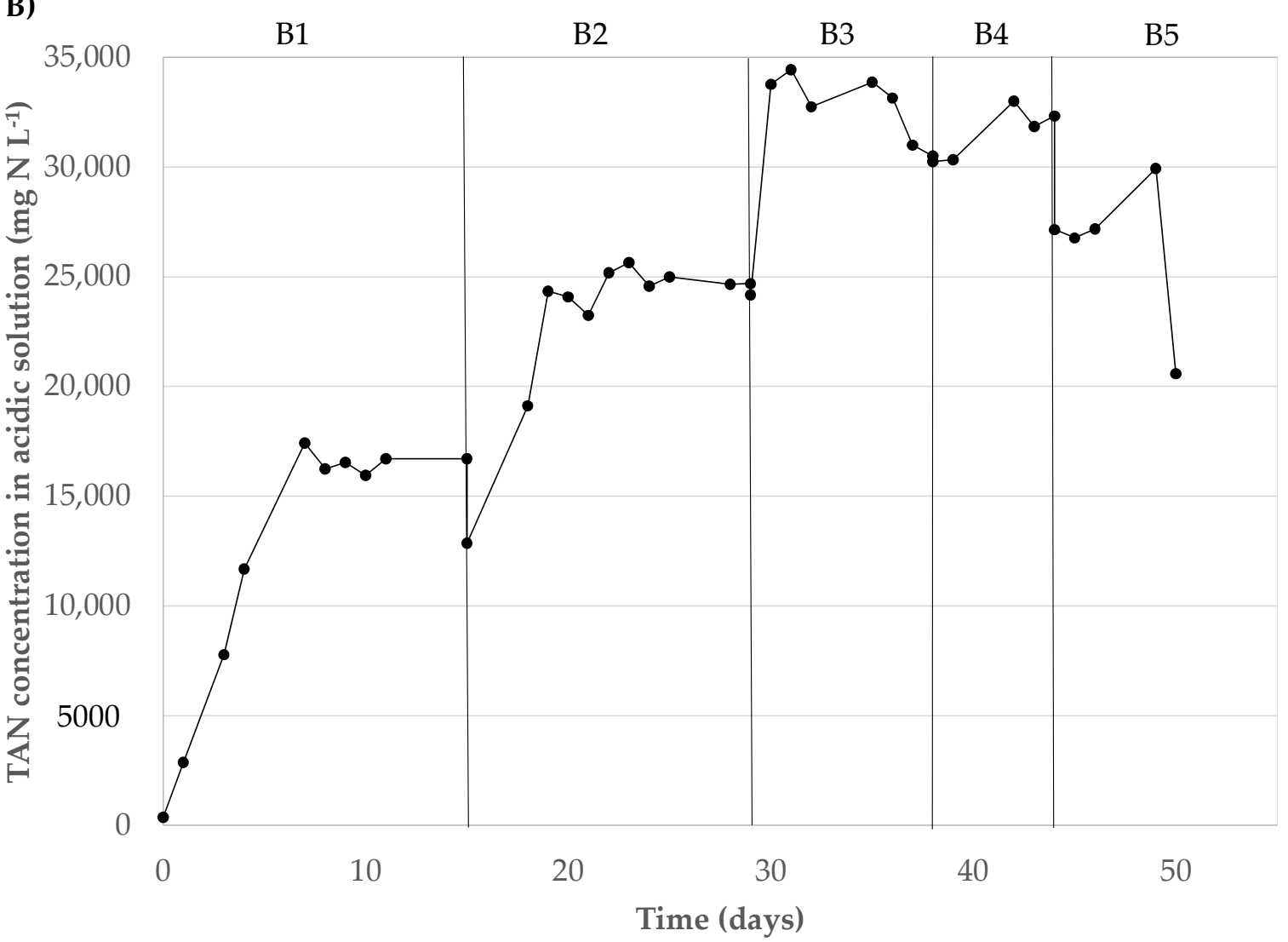

Figure 5. TAN (continuous line) and FA (dashed line) concentration in the digestate (A) and TAN concentration in the acidic trapping solution (B) in the fed-batch assay (Experiment II). 
Although the TAN concentration in the trapping solution increased during the first consecutive batches, each successive increase was not as pronounced as the previous one (Table 4; Figure 5B). For example, the TAN concentration in the trapping solution increased by $16,690 \mathrm{mg} \mathrm{N} \mathrm{L}^{-1}$ in B1, 11,822 $\mathrm{mg} \mathrm{N} \mathrm{L}^{-1}$ in B2, $6332 \mathrm{mg} \mathrm{N} \mathrm{L}^{-1}$ in B3 and $2085 \mathrm{mg} \mathrm{N} \mathrm{L}^{-1}$ in B4. TAN was even lost in $\mathrm{B} 5\left(-6550 \mathrm{mg} \mathrm{N} \mathrm{L}^{-1}\right)$. This indicates that the optimum TAN recovery occurred during $B 3$, when the maximum value of TAN concentration in the trapping solution $\left(34,429 \mathrm{mg} \mathrm{N} \mathrm{L}^{-1}\right)$ was obtained, and that additional fed-batches did not improve the process performance in terms of the TAN concentration of the trapping solution. It is worth mentioning that this maximum TAN concentration in the acidic trapping solution was approximately 14 times higher than the original digestate. Similar results were obtained by Molinuevo-Salces et al. [21], who attained a maximum TAN concentration in the trapping solution of $32,100 \mathrm{mg} \mathrm{N} \mathrm{L}^{-1}$ when treating swine manure with this pilot-scale plant. This finding also concurs with those reported by DaguerreMartini et al. [24], who studied ammonia capture from swine manure using gas-permeable membranes, and, after 4-day treatment, the TAN concentration in the acidic trapping solution was up to $37,000 \mathrm{mg} \mathrm{L}^{-1}$. Our study, as well as the two studies mentioned above, used low-rate aeration to increase the wastewater $\mathrm{pH}$ to approximately 9 . Other studies that also used the same acidic solution during the entire experiment to process various batches of manure, but that used alkali chemicals to increase the $\mathrm{pH}$ of wastewater to a higher $\mathrm{pH}$ (9-12), reported reaching higher TAN concentrations in the acidic solution, up to $53,000 \mathrm{mg} \mathrm{TAN} \mathrm{L}^{-1}$ [25] and $46,590 \mathrm{mg} \mathrm{N} \mathrm{L}^{-1}$ [26]. However, the addition of alkali chemicals to increase the wastewater $\mathrm{pH}$ is higher in cost than using the aeration approach; for example, Garcia-González et al. [14] showed that, relative to alkali addition ( $\mathrm{NaOH})$, the aeration approach reduced the operational costs of ammonia recovery by $57 \%$. Therefore, with the aeration approach, there is a limit of approximately $34,000-37,000 \mathrm{mg} \mathrm{N} \mathrm{L}^{-1}$ in the recovered solution, and if higher concentrations in the product are desired (such as to reduce the transportation cost to export this fertilizer far distances from the farm), then other methods besides alkali chemical addition need to be explored in the future, such as vacuum distillation or prilling.

\subsection{Evaluation of the Performance of the Pilot-Scale Plant Recovering Ammonia from Digestate: Digestate vs. Manure}

For the evaluation of the performance of the pilot plant for removing and recovering ammonia from digestate, four representative batches (A1, B1, C1 and C2; Tables 1 and 2) were selected and averaged, and compared with data previously obtained using the same pilot plant applied to raw swine manure (Table 5). With the digestate feed, a pH value in the digestate of up to $8.71 \pm 0.25$ and an increase of $0.86 \mathrm{pH}$ units were reached after one day of operation and maintained during the whole experimental time, due to the effect of the provided low-rate aeration. With the raw swine manure feed, the corresponding $\mathrm{pH}$ increase was 1.0 units. The average TAN removal efficiency in digestate was $34.2 \%$ (range $9.4-57.4 \%$ ), which is the same efficiency obtained with raw manure (Table 5). In the digestate case, the recovery of TAN in the trapping solution in the form of a $\left(\mathrm{NH}_{4}\right)_{2} \mathrm{SO}_{4}$ solution averaged $55.3 \%$ of the removed TAN, with a TAN recovery rate of $16.2 \mathrm{~g} \mathrm{~N} \mathrm{~m}^{-2} \mathrm{~d}^{-1}$ (range between 14.5 and $21.0 \mathrm{~g} \mathrm{~N} \mathrm{~m}^{-2} \mathrm{~d}^{-1}$ ). In the raw manure case, the recovery of TAN averaged $62.0 \%$, with a TAN recovery rate of $19.7 \mathrm{~g} \mathrm{~N} \mathrm{~m}^{-2} \mathrm{~d}^{-1}$.

In the digestate case, the trapping solution reached an averaged final TAN concentration of $14.63 \mathrm{~g} \mathrm{~N} \mathrm{~L}^{-1}$ in a single run, whereas it attained an average value of $20.74 \mathrm{~g} \mathrm{~N} \mathrm{~L}^{-1}$ when treating swine manure. Finally, in the digestate case, volatilization losses accounted for $15 \%$ of the initial TAN, similar to losses of $13 \%$ of the initial TAN in the raw manure case. This loss is higher than values ranging between 2 and $8 \%$ obtained with swine manure reactors at lab scale $[14,15]$. Possible ways to reduce ammonia losses to the atmosphere in pilot- and full-scale plants would be to cover the ammonia separation reaction tank and to use a higher ratio of membrane area per volume of liquid wastewater treated similar to the laboratory reactors. 
Table 5. Comparison of the results obtained with the GPM pilot plant during the treatment of digestate with the results obtained using the same pilot plant during the treatment of raw swine manure.

\begin{tabular}{ccccc}
\hline Parameter & \multicolumn{2}{c}{ Digestate * } & \multicolumn{2}{c}{ Raw Swine Manure ** } \\
\hline Initial $\mathrm{pH}$ & Range & Average & Range & Average \\
Final pH & $7.40-8.32$ & $7.85 \pm 0.33$ & $7.26-7.75$ & $7.60 \pm 0.21$ \\
(nitial TAN wastewater $\left(\mathrm{g} \mathrm{N} \mathrm{L}^{-1}\right)$ & $8.48-9.11$ & $8.71 \pm 0.25$ & $8.20-8.91$ & $8.61 \pm 0.30$ \\
Final TAN wastewater $\left(\mathrm{g} \mathrm{N} \mathrm{L}^{-1}\right)$ & $2.51-2.98$ & $2.73 \pm 0.17$ & $2.30-3.05$ & $2.78 \pm 0.28$ \\
Removed TAN $(\%)$ & $1.17-2.70$ & $1.82 \pm 0.58$ & $1.22-2.51$ & $1.84 \pm 0.49$ \\
Final TAN trapping solution $\left(\mathrm{g} \mathrm{N} \mathrm{L}^{-1}\right)$ & $9.44-57.37$ & $34.18 \pm 17.08$ & $14.30-49.46$ & $34.20 \pm 14.37$ \\
Recovered TAN $(\%)$ & $6.19-23.12$ & $14.63 \pm 6.17$ & $8.48-32.10$ & $20.74 \pm 10.09$ \\
TAN recovery rate $\left(\mathrm{g} \mathrm{N} \mathrm{m}^{-2} \mathrm{~d}^{-1}\right)$ & $43.16-57.52$ & $55.25 \pm 7.31$ & $42.81-79.69$ & $62.03 \pm 13.29$ \\
\hline
\end{tabular}

* Values correspond to the average of four batches comprising A1 of Experiment I and B1 of Experiment II, C1 and C2. ${ }^{* *}$ Data from Molinuevo-Salces et al. [21].

Regarding economic costs, an evaluation of the implementation of a membranebased full plant for the recovery of nitrogen from $6000 \mathrm{~m}^{3}$ of digestate generated per year $\left(16.4 \mathrm{~m}^{3}\right.$ per day) in a biogas plant with an average TAN concentration of $2.73 \mathrm{~kg} \mathrm{~m}^{-3}$ was performed. For this evaluation, a TAN recovery efficiency of $57.5 \%$ and a maximum TAN recovery rate of $21.0 \mathrm{~g} \mathrm{~N} \mathrm{~m}^{-2} \mathrm{~d}^{-1}$ were considered (Table 5). A TAN removal goal for the digestate of $90 \%$ was assumed. The amount of $\mathrm{N}$ that should be recovered per year should be $8477 \mathrm{~kg}$. The membrane needed to achieve this goal is $1107 \mathrm{~m}^{2}$. Based on the experimental data in this study, the amount of $\mathrm{H}_{2} \mathrm{SO}_{4}(96 \%)$ required for the process was $6.92 \mathrm{~kg}$ per $\mathrm{kg}$ of $\mathrm{N}$ recovered. Initial investment for this plant would amount to $150,366 €$, including the membrane, with a unit cost of $115 € \mathrm{~m}^{-2}$, and additional equipment such as pumps, tanks, the air blowing pump and the heating blanket, with an estimated value of 23,007 $€$ (Molinuevo-Salces et al. [21]). The annualized cost of the equipment would amount to $22,409 €$, considering a 10-year useful life and $8 \%$ interest. The annual operational costs would comprise the cost of $\mathrm{H}_{2} \mathrm{SO}_{4}\left(17,109 €\right.$ per year; $\left.0.29 € \mathrm{~kg}^{-1}\right)$, the cost for membrane replacement (10\% in a year), which would amount to $12,736 €$ and an electrical cost of $2822 €$ (based on an electrical power consumption of $59.7 \mathrm{kWh} \mathrm{d}^{-1}$ and a unit cost of $0.1295 € \mathrm{kWh}^{-1}$ ) [21]. As a result, the annual cost of the plant would be $55,076 €$. The revenue for the sale of the recovered nitrogen as fertilizer would be $20,005 €$ considering a value of 2,36€ per $\mathrm{kg} \mathrm{N}$ [21]. Hence, the estimated net cost of the nitrogen recovery plant would be $35,071 €$ per year, resulting in a net cost of around $4 €$ per $\mathrm{kg}$ of $\mathrm{N}$ recovered per year. This net cost is two-fold higher than the estimation made by Molinuevo-Salces et al. [21] for a membrane-based nitrogen recovery plant for a swine farm producing around $17,000 \mathrm{~m}^{3}$ of manure per year. This is mainly due to the lower TAN recovery rate obtained for the digestate compared with the manure case (20.97 vs. $38.20 \mathrm{~g} \mathrm{~m}^{-2} \mathrm{~d}^{-1}$ ) (Table 5).

\section{Conclusions}

GPM technology applied to digestate at pilot scale gave a TAN removal of $34 \%$, and up of $57.5 \%$ of the TAN removed was recovered as a $\left(\mathrm{NH}_{4}\right)_{2} \mathrm{SO}_{4}$ solution. The maximum TAN concentration in the $\left(\mathrm{NH}_{4}\right)_{2} \mathrm{SO}_{4}$ solution was nearly $35,000 \mathrm{mg} \mathrm{N} \mathrm{L}^{-1}$, which was around 14 times the TAN concentration in the original digestate. The frequent change of the trapping solution was demonstrated as an efficient strategy to increase TAN removal.

Author Contributions: Conceptualization, B.R. and B.M.-S.; formal analysis, B.R. and B.M.-S.; investigation, B.M.-S. and M.C.G.-G.; data curation, B.M.-S. and M.C.G.-G.; writing-original draft preparation, B.R.; writing-review and editing, B.R. and B.M.-S., M.B.V. and M.C.G.-G.; project administration, M.C.G.-G.; funding acquisition, M.C.G.-G. and B.R. All authors have read and agreed to the published version of the manuscript.

Funding: This research was funded by the European Union under the Project Life+ Ammonia Trapping (LIFE15-ENV/ES/000284) “Development of membrane devices to reduce ammonia emissions 
generated by manure in poultry and pig farms". The mention of trade names or commercial products in this article is solely for the purpose of providing specific information and does not imply recommendation or endorsement by the USDA.

Conflicts of Interest: The authors declare no conflict of interest.

\section{References}

1. Grando, R.L.; Antune, A.M.D.S.; da Fonseca, F.V.; Sánchez, A.; Barrena, R.; Font, X. Technology overview of biogas production in anaerobic digestion plants: A European evaluation of research and development. Renew. Sustain. Energy Rev. 2017, 80, 44-53. [CrossRef]

2. Riva, C.; Orzi, V.; Carozzi, M.; Acutis, M.; Boccasile, G.; Lonati, S.; Tambone, F.; D’Imporzano, G.; Adani, F. Short-term experiments in using digestate products as substitutes for mineral $(\mathrm{N})$ fertilizer: Agronomic performance, odours, and ammonia emission impacts. Sci. Total. Environ. 2016, 547, 206-214. [CrossRef]

3. Iglesias, R.; Muñoz, R.; Polanco, M.; Díaz, I.; Susmozas, A.; Moreno, A.; Guirado, M.; Carreras, N.; Ballesteros, M. Biogas from Anaerobic Digestion as an Energy Vector: Current Upgrading Development. Energies 2021, 14, 2742. [CrossRef]

4. Nkoa, R. Agricultural benefits and environmental risks of soil fertilization with anaerobic digestates: A review. Agron. Sustain. Dev. 2014, 34, 473-492. [CrossRef]

5. EC-European Commission. Directive (EU) 2016/2284 of the European Parlament and of the Council of 14 December 2016 on the reduction of national emissions of certain atmospheric pollutants, amending Directive 2003/35/EC and repealing Directive 2001/81/EC. Off. J. Eur. Common. 2016, L344, 1-31.

6. European Council. Council Directive of 12 December 1991 Concerning the Protection of Waters Against Pollution Caused by Nitrates from Agricultural Sources (91/676/EEC). Off. J. 1991, 375, 1-8.

7. Folino, A.; Zema, D.A.; Calabrò, P.S. Environmental and Economic Sustainability of Swine Wastewater Treatments Using Ammonia Stripping and Anaerobic Digestion: A Short Review. Sustainability 2020, 12, 4971. [CrossRef]

8. Milan, Z.; Sánchez, E.; Weiland, P.; de Las Pozas, C.; Borja, R.; Mayari, R.; Rovirosa, N. Ammonia removal from anaero-bically treated piggery manure by ion exchange in columns packed with homoionic zeolites. Chem. Eng. J. 1997, 66, 65-71. [CrossRef]

9. Demirer, S.U.; Demirer, G.; Chen, S. Ammonia removal from anaerobically digested dairy manure by struvite precipitation. Process. Biochem. 2005, 40, 3667-3674. [CrossRef]

10. Masse, L.; Massé, D.; Pellerin, Y.; Dubreuil, J. Osmotic pressure and substrate resistance during the concentration of manure nutrients by reverse osmosis membranes. J. Membr. Sci. 2010, 348, 28-33. [CrossRef]

11. Vanotti, M.B.; Szogi, A.A. Systems and Methods for Reducing Ammonia Emissions from Liquid Effluents and for Recov-Ering the Ammonia. U.S. Patent 9,005,333 B1, 14 April 2015.

12. Munasinghe-Arachchige, S.P.; Nirmalakhandan, N. Nitrogen-Fertilizer Recovery from the Centrate of Anaerobically Digested Sludge. Environ. Sci. Technol. Lett. 2020, 7, 450-459. [CrossRef]

13. Dube, P.J.; Vanotti, M.B.; Szogi, A.A.; Garcia-González, M.C. Enhancing recovery of ammonia from swine manure an-aerobic digester effluent using gas-permeable membrane technology. Waste Manag. 2016, 49, 372-377. [CrossRef] [PubMed]

14. Garcia-González, M.; Vanotti, M. Recovery of ammonia from swine manure using gas-permeable membranes: Effect of waste strength and pH. Waste Manag. 2015, 38, 455-461. [CrossRef] [PubMed]

15. García-González, M.; Vanotti, M.; Szogi, A. Recovery of ammonia from swine manure using gas-permeable membranes: Effect of aeration. J. Environ. Manag. 2015, 152, 19-26. [CrossRef] [PubMed]

16. Zarebska, A.; Romero Nieto, D.; Christensen, K.V.; Norddahl, B. Ammonia recovery from agricultural wastes by mem-brane distillation: Fouling characterization and mechanism. Water Res. 2014, 45, 1-10. [CrossRef]

17. Bayrakdar, A.; Sürmeli, R.; Önder; Çalli, B. Anaerobic digestion of chicken manure by a leach-bed process coupled with side-stream membrane ammonia separation. Bioresour. Technol. 2018, 258, 41-47. [CrossRef]

18. Riaño, B.; Molinuevo-Salces, B.; Vanotti, M.B.; García-González, M.C. Application of Gas-Permeable Membranes For-SemiContinuous Ammonia Recovery from Swine Manure. Environments 2019, 6, 32. [CrossRef]

19. García-González, M.C.; Vanotti, M.B.; Szogi, A.A. Recovery of ammonia from anaerobically digested manure using gas-permeable membranes. Sci. Agric. 2016, 73, 434-438. [CrossRef]

20. González-García, I.; Riaño, B.; Molinuevo-Salces, B.; Vanotti, M.; García-González, M. Improved anaerobic digestion of swine manure by simultaneous ammonia recovery using gas-permeable membranes. Water Res. 2021, 190, 116789. [CrossRef]

21. Molinuevo-Salces, B.; Riaño, B.; Vanotti, M.B.; Hernández-González, D.; García-González, M.C. Pilot-Scale Demonstration of Membrane-Based Nitrogen Recovery from Swine Manure. Membranes 2020, 10, 270. [CrossRef]

22. American Water Works Association; Water Environment Federation. Standard Methods for the Examination of Water, Wastewater APHA, 21st ed.; American Public Health Association: Washington, DC, USA, 2005.

23. Hansen, K.H.; Angelidaki, I.; Ahring, B.K. Anaerobic Digestion of Swine Manure: Inhibition by Ammonia. Water Res. 1998, 32 , 5-12. [CrossRef]

24. Daguerre-Martini, S.; Vanotti, M.; Rodriguez-Pastor, M.; Rosal, A.; Moral, R. Nitrogen recovery from wastewater using gaspermeable membranes: Impact of inorganic carbon content and natural organic matter. Water Res. 2018, 137, 201-210. [CrossRef] [PubMed] 
25. Vanotti, M.B.; Szogi, A.A. Use of Gas-Permeable Membranes for the Removal and Recovery of Ammonia from High Strength Livestock Wastewater. In Proceedings of the WEF/IWA Nitrogen Recovery and Management Conference, Miami, FL, USA, 9-12 January 2011.

26. García, M.C.; Vanotti, M.B.; Szogi, A.A. Abatement of ammonia emissions from digested manure using gas-permeable membranes. In Proceedings of the RAMIRAN 2015-16th International Conference Rural-Urban Symbiosis, Hamburg, Germany, 8-10 September 2015; pp. 310-313. 